\title{
Differentially expressed circRNAs in melanocytes and melanoma cells and their effect on cell proliferation and invasion
}

\author{
QI WANG ${ }^{1}$, JIA CHEN $^{2}$, AIJUN WANG $^{3}$, LICHUN SUN $^{4}$, LI QIAN $^{5}$, XIAO ZHOU $^{6}$, YU LIU $^{2}$, \\ SHIJIE TANG ${ }^{7}, \mathrm{XIANG} \mathrm{CHEN}^{8}, \mathrm{YAN} \mathrm{CHENG}^{9}, \mathrm{KE} \mathrm{CAO}^{1 *}$ and JIANDA ZHOU ${ }^{2 *}$
}

Departments of ${ }^{1}$ Oncology and ${ }^{2}$ Plastic and Reconstructive Surgery, The Third Xiangya Hospital of Central South University, Changsha, Hunan 410013, P.R. China; ${ }^{3}$ Surgical Bioengineering Laboratory, Department of Surgery, University of California, Davis School of Medicine, Sacramento, CA 95817; ${ }^{4}$ School of Medicine, Tulane University Health Sciences Center, New Orleans, LA 70112, USA; ${ }^{5}$ Department of Plastic and Reconstructive Surgery, The Second Xiangya Hospital of Central South University, Changsha, Hunan 410011; ${ }^{6}$ Department of Head and Neck Surgery,

Department of Oncology Plastic Surgery, Hunan Province Cancer Hospital and The Affiliated Cancer Hospital of

Xiangya School of Medicine, Central South University, Changsha, Hunan 410006;

${ }^{7}$ Department of Burn and Plastic Surgery, The Second Affiliated Hospital, Shantou University Medical College,

Shantou, Guangdong 515041; ${ }^{8}$ Department of Dermatology, Xiangya Hospital of Central South University,

Changsha, Hunan 410008; ${ }^{9}$ Department of Pharmacology, School of Pharmaceutical Sciences,

Central South University, Changsha, Hunan 410013, P.R. China

Received May 8, 2017; Accepted January 31, 2018

DOI: $10.3892 /$ or.2018.6263

\begin{abstract}
Circular RNAs (circRNAs) play critical roles in the occurrence of human diseases, including cancer. However, the detailed functions of circRNAs in melanoma have not been fully elucidated. In the present study, a circRNA microarray was performed to analyze the variability of circRNAs in the low-metastatic melanoma WM35 cell line and in the high-metastatic melanoma WM451 cell line in comparison to control human melanocytes. The results revealed that five circRNAs were upregulated and four circRNAs were downregulated in both the WM35 and WM451 cells. qRT-PCR revealed an upregulated expression of circ0000082 and circ0016418 and a downregulation of circ0023988, circ0008157 and circ0030388 in the cells which was consistent with the results of the microarray assay. Functional tests revealed that knockdown of circ 0023988 , circ 0008157 or circ0030388 significantly promoted the proliferation and invasion of the WM35 cells.
\end{abstract}

Correspondence to: Professor Jianda Zhou, Department of Plastic and Reconstructive Surgery, The Third Xiangya Hospital of Central South University, Changsha, Hunan 410013, P.R. China

E-mail: zhoujianda@csu.edu.cn

Professor Ke Cao, Department of Oncology, The Third Xiangya Hospital of Central South University, Changsha, Hunan 410013, P.R. China

E-mail: csucaoke@163.com

*Contributed equally

Key words: circular RNA, melanoma, siRNA, ceRNA, miRNA
Following the silencing of circ0000082 or circ0016418 in WM451 cells, the proliferation and invasion of the WM451 cells were inhibited. Bioinformatic analysis predicted that the circ0000082-, circ0023988- and circ0008157-circRNAmiRNA-mRNA network may participate in the occurrence, development, invasion and metastasis of malignant tumors. The present study revealed several differentially expressed circRNAs, indicating that the newly identified circRNAs may provide new therapeutic targets for melanoma.

\section{Introduction}

Melanoma is a highly malignant skin tumor derived from melanocytes and its incidence has been rapidly increasing worldwide (1). Melanoma is not sensitive to radiotherapy, chemotherapy or biological immunotherapy and metastasizes at an early clinical stage (2). Therefore, it is crucial to understand the molecular mechanisms underlying the development of melanoma. Although researchers worldwide have performed extensive research on gene mutations, epigenetics, immune abnormalities and the tumor microenvironment of melanoma, its precise mechanism remains poorly understood. Studies on non-coding RNA, notably circular RNA (circRNA), may provide a breakthrough for the explanation of the mechanism of melanoma and the identification of early intervention targets and biomarkers for early diagnosis.

Circular RNAs (circRNAs) have been reported as a novel type of non-coding RNAs, which form covalently-closed continuous loops without 5 ' to 3 ' polarity or polyadenylated tails $(3,4)$. They mainly arise from exons or introns and are differentially generated by back-splicing or lariat-introns (5). circRNAs are characterized by stable structure, high abundance and tissuespecific expression. These characteristics imply that circRNAs 
hold a great potential as novel clinical diagnostic and prognostic markers and as new treatment targets of diseases (6-8). Increasing evidence has revealed that circRNAs specifically serve as miRNA sponges, regulate alternative splicing and modulate the expression of parental genes (9-11). It has been proved that circRNA-CDR1 contains miR-7 binding sites and exerts a negative regulatory effect in miR-7 as an endogenous miRNA sponge and an upregulator of miR-7-targeted genes in the nervous system $(12,13)$. In esophageal squamous cell carcinoma, cir-ITCH was downregulated in cancerous tissue and functioned as a sponge of miR-7, miR-17 and miR-214. Therefore, it enhanced the level of ITCH which negatively regulates the Wnt/ $\beta$-catenin signaling pathway (14).

To date, a study concerning the expression of circRNAs in melanoma has not been reported. Therefore, in the present study, we performed the profiling of circRNA expression in normal melanocytes and melanoma cells with different invasive abilities using circRNA microarray analysis. Furthermore, we investigated differentially expressed circRNAs, as well as the changes in melanoma cell proliferation and invasion after circRNA-siRNA transfection. In addition, we analyzed the features of the circRNA-expression profiling and predicted miRNAs competitively binding to circRNAs. Finally, we provided important experimental evidence for clarifying the occurrence, the development, the invasion and metastasis of melanoma and for exploring the non-coding RNA regulatory networks related to the malignant phenotype of melanoma.

\section{Materials and methods}

Cell culture and reagents. The human melanocytes HM, the low-metastatic melanoma cell line WM35 and the highmetastatic melanoma cell line WM451 were purchased from the American Type Culture Collection (ATCC; Manassas, VA, USA). The cells were incubated with Dulbecco's modified Eagle's medium (DMEM; Gibco; Thermo Fisher Scientific, Inc., Waltham, MA, USA) containing $10 \%$ fetal bovine serum (FBS) in a $5 \% \mathrm{CO}_{2}$ incubator at $37^{\circ} \mathrm{C}$. The reagents in the present study included an RNA-free extraction kit (Invitrogen Life Technologies, Carlsbad, CA, USA), an Opti-MEM I ReducedSerum medium (Invitrogen Life Technologies), Transwell 6 -well plates, $(8-\mu \mathrm{m}$ pore size; Corning Incorporated, Corning, NY, USA), Matrigel basement membrane (Becton, Dickinson and Company, Franklin Lakes, NJ, USA), RNase-free glycogen in RNase water (Invitrogen Life Technologies), Arraystar Human circRNA Array (8x15 K; Arraystar, Rockville, MD, USA) including 5,396 circRNAs, GoldView dye (SBS Genetech Co., Ltd., Shanghai, China), 2X PCR Master Mix (Arraystar) and SuperScript ${ }^{\mathrm{TM}}$ III Reverse Transcriptase (Invitrogen Life Technologies). The experiments were conducted by Kangchen Biotech Co., Ltd. (Shanghai, China).

RNA extraction. Total RNA was extracted from the cells using the RNA extraction kit according to the manufacturer's instructions and examined by $1 \%$ agarose gel electrophoresis. Both the $28 \mathrm{~S}$ and $18 \mathrm{~S}$ bands were clear and the brightness of the $28 \mathrm{~S}$ band was roughly two-fold higher than that of the $18 \mathrm{~S}$ band, indicating the integrity of total RNA. Ultraviolet spectrophotometry was used to determine the concentration and purity of RNA. The D260/D280 nm ratio was 1.8-2.1 These results indicated that the purity of total RNA was suitable for subsequent circRNA microarray analysis and quantitative fluorescence PCR.

circRNA microarray. For analyzing the acquired array images, the Agilent Feature Extraction software (version 11.0.1.1; Agilent Technologies, Inc., Santa Clara, CA, USA) was performed. Following the instructions of the Arraystar Super RNA Labeling kit (Arraystar), total RNA of each sample was amplified with random primers and reverse transcribed into fluorescent-labeled cRNA. Subsequently, fluorescent-labeled cRNA was hybridized on an Arraystar Human circRNA Array (8x15 K; Arraystar) and then incubated in an Agilent Hybridization oven at $65^{\circ} \mathrm{C}$ for $17 \mathrm{~h}$. After washing, the samples were scanned on an Agilent scanner (G2505C).

Data collection and analysis of circRNA microarray. Fluorescence intensity was scanned in a microarray scanner and loaded to the Agilent Feature Extraction software to read and analyze the original data. The $\mathrm{R}$ software package (limma package, Cytoscape http://www.cytoscape.org/ 3.3.2, R environment https://www.r-project.org/ reversion 3.42) was used for quantile normalization and subsequent data processing. Differentially expressed circRNAs between groups was screened by fold change and $\mathrm{P}$-value. A value of $\mathrm{P}<0.05$ was considered to indicate a statistically significant difference. Cluster analysis revealed differential circRNA expression using Cluster 3.0 software ( $\mathrm{R}$ programming language package: Gplots).

Predictionfor circRNA-miRNA-mRNAnetwork. The circRNAmicroRNA interaction was predicted using Arraystar miRNA target-prediction software (Arraystar) and GCBI (https://www. gcbi.com.cn/gclib/html/index) based on TargetScan and miRanda software packages. A site with a higher matching score was noted. The map of circRNA-miRNA interaction network was illustrated using Cytoscape 3.01 (Cytoscape Consortium San Diego, CA, USA).

Real-time quantitative fluorescence PCR. Five differentially expressed circRNAs were verified by real-time quantitative fluorescence PCR. Reverse transcription reaction was carried out according to the instructions of the SuperScript ${ }^{\mathrm{TM}}$ III Reverse Transcriptase reverse transcription kit (Invitrogen Life Technologies). The ViiA ${ }^{\mathrm{TM}} 7$ Real-Time PCR system was used for quantitative detection of PCR. The PCR primers were designed and synthesized by Invitrogen Biotechnology Co., Ltd. (Shanghai, China). The primer sequences and related information are listed in Table I. GAPDH served as an internal standard for normalization. The PCR conditions were as follows: $95^{\circ} \mathrm{C}$ for $10 \mathrm{~min}, 95^{\circ} \mathrm{C}$ for $10 \mathrm{sec}$ and $60^{\circ} \mathrm{C}$ for $60 \mathrm{sec}$, for a total of 40 cycles. The $2^{-\Delta \Delta \mathrm{Ct}}$ value refers to the relative expression level of circRNAs. The experiments were performed in triplicate.

Transfection. The cells were transfected with five differentially expressed circRNAs which were verified using qRT-PCR as follows: $24 \mathrm{~h}$ before transfection, $5 \times 10^{4}$ cells were seeded in $2 \mathrm{ml}$ of basal medium containing FBS. The cells were ready for transfection when they reached $70 \%$ 
Table I. The primers for qRT-PCR.

Gene

Primer sequence

Length (bp)

$\begin{array}{ll}\text { GAPDH } & \text { F: 5'GGGAAACTGTGGCGTGAT3' } \\ & \text { R: 5'GAGTGGGTGTCGCTGTTGA3' } \\ \text { circRNA0000082 } & \text { F: 5'CGGATTAGAAACCTCGACACC3' } \\ & \text { R: 5'TGGACCACAGGAGCATCATT3' } \\ \text { circRNA0016418 } & \text { F: 5'CTCCGACCCAAGTGAGAAGC3' } \\ \text { circRNA0023988 } & \text { R: 5'CAGCCTGTAGTTTGGGACC3' } \\ \text { circRNA0008157 } & \text { F: 5'TGGTGGTGGTGCTATTCCTC3' } \\ & \text { R: 5'TCTCCTGGTTCTCCTGCTTG3' } \\ \text { circRNA0030388 } & \text { F: 5'GAATTCTAAGCAGCACAACATCA3' } \\ & \text { R: 5'GGGTCCATGTCTTTGCCTCT3' } \\ & \text { F: 5'TGGGACATCCATCAGATAAGAA3' } \\ & \text { R: 5'CTGTAGTGGGAGGCAGTGTTT3' }\end{array}$

F, forward; R, reverse.

confluency. Lipofectamine ${ }^{\mathrm{TM}} 2000(5 \mu \mathrm{l})$ was diluted in $250 \mu \mathrm{l}$ of Opti-MEM ${ }^{\circledR} \mathrm{I}$, mixed gently and incubated at room temperature for $5 \mathrm{~min}$, and then $7.5 \mu \mathrm{l}$ siRNA-circRNAs was diluted in $250 \mu \mathrm{l}$ of Opti-MEM ${ }^{\circledR} \mathrm{I}$, mixed gently and incubated at room temperature for $5 \mathrm{~min}$. Diluted siRNA-circRNAs and Lipofectamine $^{\mathrm{TM}} 2000$ were mixed together gently and the complexes were incubated at room temperature for $20 \mathrm{~min}$. The siRNA-circRNAs-Lipofectamine ${ }^{\mathrm{TM}} 2000$ transfection complexes were added in 6-well plates and mixed by gently rocking the plate back and forth. The plates were incubated at $37^{\circ} \mathrm{C}$ in a $\mathrm{CO}_{2}$ incubator for $24-72 \mathrm{~h}$. The transfected cells were observed under a fluorescence microscope (CKX53; Olympus, Tokyo, Japan) to assess the transfection efficiency.

Cell proliferation assay. After transfection, the cell density in each group was adjusted to $1 \times 10^{5}$ cells $/ \mathrm{ml}$ and the cells were seeded in 96-well plates in a volume of $100 \mu \mathrm{l}$ per well, and placed at $37^{\circ} \mathrm{C}$ in a $\mathrm{CO}_{2}$ incubator for $24 \mathrm{~h}$. The WM35 cells were divided into four groups: i) negative control group, ii) si-circ0023988, iii) si-circ0008157 and iv) si-circ0030388 treated group. The WM451 cells were divided into three groups: i) negative control, ii) si-circ0000082 and iii) si-circ0016418 group. Methyl thiazolyl tetrazolium (MTT) $(50 \mu 1,1 \mathrm{mg} / \mathrm{ml})$ was added to each well and the plates were incubated for $4 \mathrm{~h}$ at $37^{\circ} \mathrm{C}$, until MTT was reduced to formazan. The supernatant was aspirated and $150 \mu \mathrm{l}$ DMSO was added to each well, and then the plates were placed on a horizontal shaker and shaked for $10 \mathrm{~min}$ to dissolve the formazan. The optical density (OD) value of each well was detected using an enzyme-linked immunosorbent assay (ELISA) reader at $570 \mathrm{~nm}$. Cells without treatment served as a control and the blank well was used for zero adjustment. The cell survival rate were calculated using the following formula: Cell survival rate $=(\mathrm{OD}$ value of the experiment group/OD value of the control group) $\mathrm{x} 100 \%$.

Cell invasion assay. The upper chamber surface of the basement membrane of the Transwell chambers was coated with
$50 \mathrm{mg} / 1$ Matrigel 1:8 dilution and air dried at $4^{\circ} \mathrm{C}$. Diluted Matrigel (60-80 $\mu \mathrm{l}, 3.9 \mu \mathrm{g} / \mu \mathrm{l})$ was added to the polycarbonate membrane in the upper chamber and placed at $37^{\circ} \mathrm{C}$ for $30 \mathrm{~min}$ to allow the Matrigel to polymerize. The cells were digested and after terminating the digestion, the cells were centrifuged and then the culture medium was discarded. After washing with PBS for 1-2 times, the cells were resuspended in serum-free media containing bovine serum albumin (BSA). The cell density was adjusted to $5 \times 10^{4} / \mathrm{ml}$. One milliliter of medium-containing FBS was added to the lower chambers of 6-well plates, cell supernatant was added to the upper chambers and after 72 and 24-h incubation for the WM451 and the WM35 cells respectively, the membranes were removed. The cells on the Matrigel and upper chambers were removed with a cotton swab, the membrane was removed and fixed with 95\% alcohol for 15-20 min and stained with hematoxylin for $10 \mathrm{~min}$. The cells were counted and imaged under an inverted microscope (CKX53; Olympus).

Statistical analysis. The data are presented as the mean \pm SD as analyzed using SPSS 13.0 (SPSS, Inc., Chicago, IL, USA) and deemed to have statistical significance at $\mathrm{P}<0.05$ using the Student's t-test, one-way analysis of variance (ANOVA) or $\chi^{2}$ test.

\section{Results}

Differentially expressed circRNAs. Genome scan (Fig. 1A) and cluster analysis (Fig. 1B) were used to identify abnormal expression of circRNAs among the HM, WM35 and WM451 cells. Approximately 5,396 circRNAs were detected using the Arraystar Human circRNA Array data analysis. The results of the heat maps are displayed in Fig. 1B. The data obtained from circRNA microarray analysis were normalized. Approximately 5,396 circRNAs were detected by the Arraystar Human circRNA Array data. The results of the genome scans and differentially expressed circRNAs among 
A

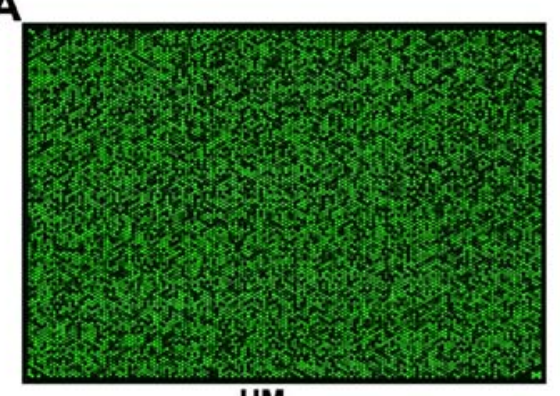

HM

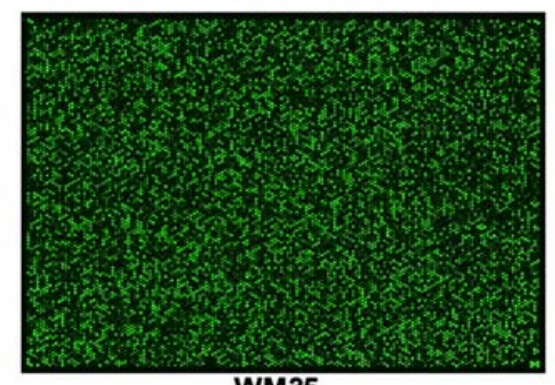

WM35

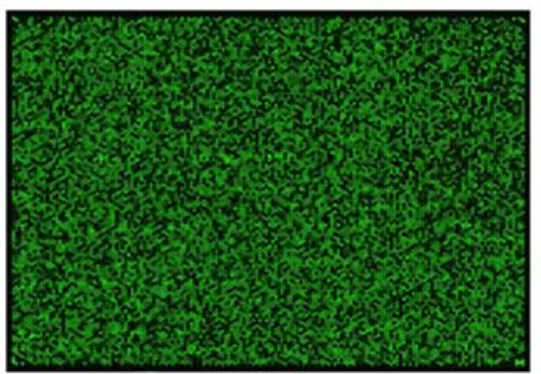

WM451
B

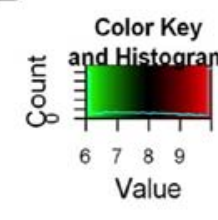

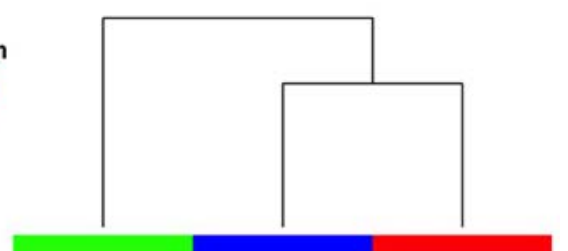

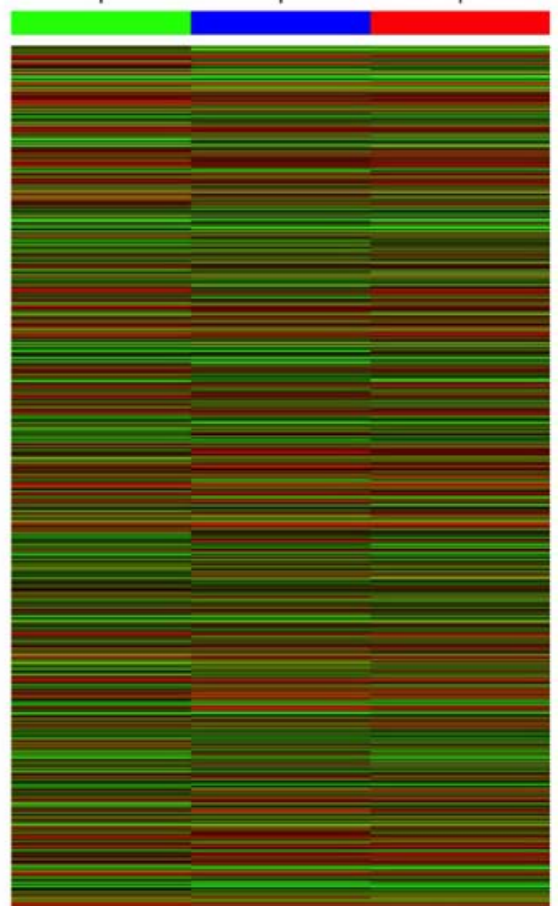

HM

WM35

WM451

Figure 1. CircRNA array results. (A) Microarray hybridization image: Arraystar Human circRNA Array detected 5,396 circRNAs in HM, WM35 and WM451 cells. The genome scans of HM, WM35 and WM451 cells. (B) Hierarchical Clustering: The hot map and hierarchical clustering of partially differentially expressed circRNAs among HM, WM35 and WM451 cells. Red, High expression; green, Low expression.

the HM, WM35 and WM451 cells are displayed in Fig. 1. Data obtained from circRNA microarray analysis were normalized. circRNAs with expression levels that increased 2-fold were upregulated and circRNAs with expression levels that decreased 2-fold were downregulated. Different fold changes of circRNA expression according to chip analyses are summarized in Table II. CircRNA microarray analysis results demonstrated that compared with HM cells, 797 circRNAs were upregulated and 969 circRNAs were downregulated in WM35 cells, while 307 circRNAs were upregulated and 312 circRNAs were downregulated in WM451 cells. Only five circRNAs (circ0001056, circ0000082, circ0016418, circ0008602 and circ0033496) were upregulated as well as four circRNAs (circ0023988, circ0008157, circ0030388 and circ0023990) were downregulated both in WM35 and WM451 cells. Compared with the WM35 cells, 977 circRNAs were upregulated and 757 circRNAs were downregulated in the WM451 cells (Table II). In WM35 vs. HM cells, WM451 vs. HM cells and WM451 vs. WM35 cells, four circRNAs (circ0023988, circ0023990, circ0008157 and circ0030388) were all downregulated (Table III).

Differential expression of circRNAs verified by real-time quantitative fluorescence PCR. Five upregulated circRNAs and four downregulated circRNAs were found by microarray analysis and qRT-PCR was used to verify the background expression levels of the above-mentioned circRNAs in melanoma cells. GAPDH served as an internal standard for normalization. The results revealed that circ0000082 and circ0016418 had higher expression levels and circ0023988, circ0008157 and circ0030388 had lower expression levels both in the WM35 and the WM451 cells, compared with the HM cells (Fig. 2). The above-mentioned five circRNAs were verified by real-time quantitative fluorescence PCR and the PCR results were generally consistent with those of the circRNA microarray, which confirmed that the microarray analysis results were reliable (Table IV). The other four circRNAs with low basal expression were excluded (circ0001056, circ0033496, circ0008602 and circ0023990).

Knockdown of the expression levels of circRNAs. In order to interfere with circRNA expression levels, circ0023988, circ0008157, or circ0030388 siRNAs were transfected into WM35 cells, while circ0000082 or circ0016418 siRNA swere transfected into WM451 cells. The highest transfection efficiency was observed at $24 \mathrm{~h}$ and the transfection efficiency was $>80 \%$ by comparing the cells in bright field and fluorescent views of the same field (Fig. 3). Therefore, these results 
Table II. Differential expression of circRNA according to chip analyses.

A, Upregulated circRNA

\begin{tabular}{lcrr}
\hline Fold change & WM35 vs. HM & WM451 vs. HM & WM451 vs. WM35 \\
\hline$>20$ & 0 & 0 & 2 \\
$10-20$ & 0 & 5 & 32 \\
$5-10$ & 2 & 26 & 126 \\
$2-5$ & 795 & 276 & 817 \\
\hline
\end{tabular}

B, Downregulated circRNA

\begin{tabular}{lrrr}
\hline$>20$ & 1 & 5 & 1 \\
$10-20$ & 10 & 8 & 0 \\
$5-10$ & 89 & 20 & 13 \\
$2-5$ & 869 & 279 & 743 \\
\hline
\end{tabular}

circRNA, circular RNA.

Table III. Differential expression of circRNAs according to chip analyses.

A, Upregulated

Fold change

\begin{tabular}{lccl} 
circRNA & WM35 vs. HM & WM451 vs. HM & \multicolumn{1}{c}{ miRNA binding sites } \\
\hline circ0001056 & 3.45 & 2.13 & miR-30b-3p, miR-619-5p, miR-665, miR-153-5p, miR-149-5p \\
circ0000082 & 2.39 & 4.65 & miR-30b-3p, miR-23a-5p, miR-143-5p, miR-106b-3p, miR-508-5p \\
circ0016418 & 2.63 & 3.63 & miR-214-5p, miR-153-5p, miR-657, miR-450a-2-3p, miR-605-3p \\
circ0008602 & 2.69 & 3.28 & miR-544a, miR-200c-3p, miR-148a-3p, miR-362-5p, miR-17-3p \\
$\operatorname{circ0033496}$ & 2.031 & 2.15 & miR-612, miR-502-5p, miR-1264, miR-105-3p, miR-423-5p
\end{tabular}

B, Downregulated

\begin{tabular}{lcccl}
\hline & \multicolumn{3}{c}{ Fold change } & \\
\cline { 2 - 3 } circRNA & WM35 & WM451 & WM451 & \\
\hline circ0023988 & -2.08 & -5.64 & -2.71 & miR-655-5p, miR-448, miR-485-5p, miR-613, miR-103a-3p \\
circ0023990 & -2.55 & -10.12 & -3.96 & miR-485-5p, miR-613, miR-339-5p, miR-329-5p, miR-873-5p \\
circ0008157 & -2.38 & -4.92 & -2.06 & miR-136-3p, miR-365b-5p, miR-365a-5p, miR-329-5p, miR-335-3p \\
circ0030388 & -2.39 & -17.82 & -7.45 & miR-449b-5p, miR-449a, miR-34a-5p, miR-34c-5p, miR-200a-3p \\
\hline
\end{tabular}

circRNAs, circular RNAs.

indicated that the transfection efficiency was satisfactory and the cells could be used for the following experiments.

Changes in cell proliferation after siRNA-circRNAs transfection. Twenty-four hours after the WM35 and WM451 cells were transfected with siRNA-circRNAs, the cell proliferation in each group was detected by an MTT assay. The results revealed that at 24 and $48 \mathrm{~h}$ after transfection, the OD values of low-metastatic melanoma WM35 cells in the si-circ0023988, si-circ0008157 and si-circ0030388 groups were significantly higher than that in the negative control group $(\mathrm{P}<0.05)$, indicating that silencing of circ0023988, 
A

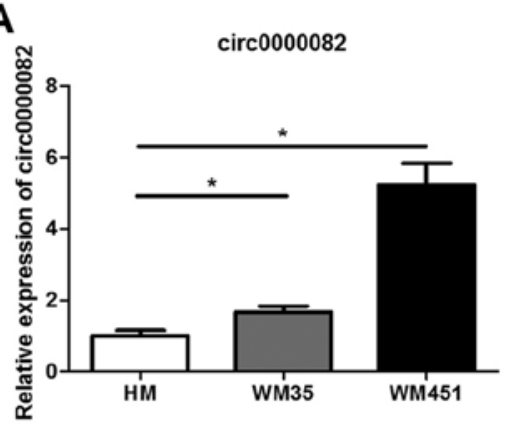

B

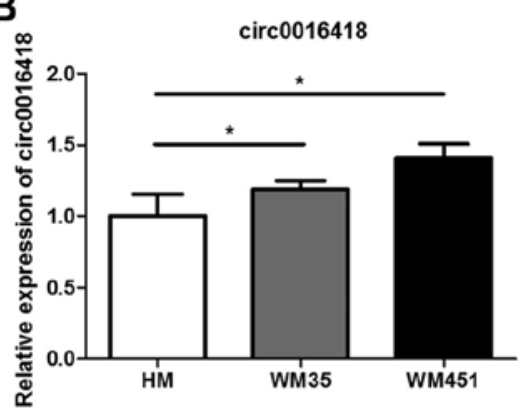

C

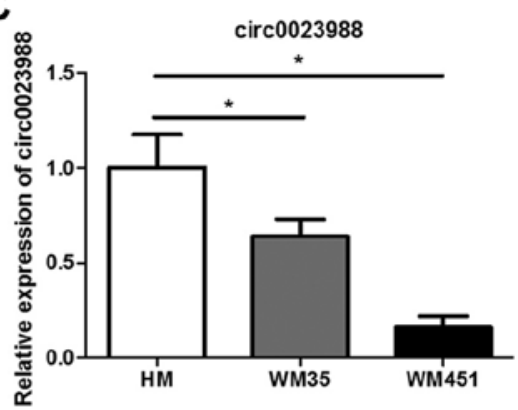

D

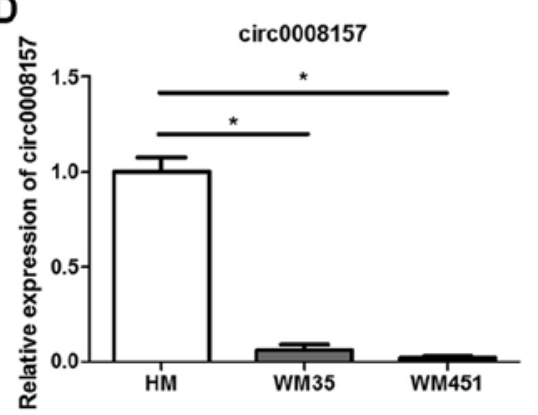

E

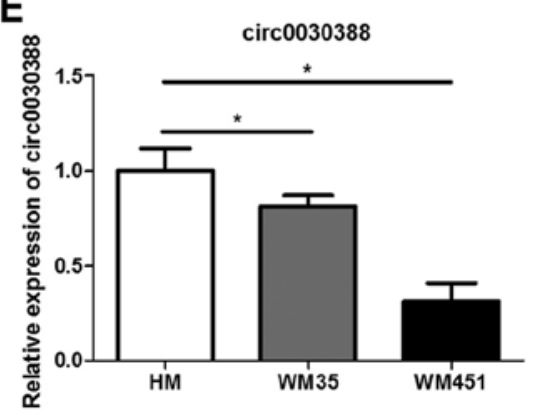

Figure 2. The background expression of identified circRNA. The relative expression of (A) circ0000082, (B) circ0016418, (C) circ0023988, (D) circ0008157 and (E) circ0030388 in HM, WM35 and WM451 cells by real time RT-PCR. ${ }^{*} \mathrm{P}<0.05$.

Table IV. Differential expression of circRNAs according to qRT-PCR.

Fold change

\begin{tabular}{lcccc}
\cline { 2 - 5 } circRNA & WM35 vs. HM & WM451 vs. HM & WM451 vs. WM35 & Expression \\
\hline circ0000082 & 1.67 & 5.23 & 3.31 & Up \\
circ0016418 & 1.19 & 1.41 & 1.19 & Up \\
circ0023988 & 0.64 & 0.16 & 0.24 & Down \\
circ0008157 & 0.056 & 0.02 & 0.268 & Down \\
circ0030388 & 0.816 & 0.31 & 0.384 & Down \\
\hline
\end{tabular}

Up, upregulated; Down, downregulated; circRNAs, circular RNAs.

circ0008157 and circ0030388 promoted the proliferation of the WM35 cells (Fig. 4A). At 24, 48 and $72 \mathrm{~h}$ after transfection, the OD values of high-metastatic melanoma WM451 cells in the si-circ0000082 and si-circ0016418 groups were significantly lower than that in the negative control group $(\mathrm{P}<0.05)$, indicating that silencing of circ0000082 and circ0016418 inhibited the proliferation of the WM451 cells (Fig. 4B).

Changes in cell invasion after siRNA-circRNA transfection. The transfected WM35 and WM451 cells were subjected to invasion assays for 24 and $72 \mathrm{~h}$, respectively. The cells that passed through the basement membrane were counted by light microscope (CKX53; Olympus) at x200 magnification. The cell numbers in the si-circ0023988, si-circ0008157 and si-circ0030388 groups were $87.3 \pm 12,103.3 \pm 10$ and $88.3 \pm 5.7$, respectively, which were significantly higher than these in the negative control group $(34.3 \pm 1.5)(\mathrm{P}<0.05$, Fig. $5 \mathrm{~A})$, indicating that the invasion ability of low-metastatic melanoma WM35 cells was enhanced by silencing of circ0023988, circ0008157 and circ0030388. Compared with the negative control group, the WM451 cell numbers in the si-circ0000082 and si-circ0016418 groups were lower $(48.3 \pm 3.5,44.3 \pm 5$ vs. $86.3 \pm 5.1)(\mathrm{P}<0.05$, Fig. $5 \mathrm{~B})$. These results indicated that silencing of circ0000082 and circ0016418 decreased the invasion capability of high-metastatic melanoma WM451 cells and that circ0000082 and circ0016418 have a promoting effect on the invasion of WM451 cells.

Competing endogenous RNA (ceRNA) analysis of circ0000082, circ0023988 and circ0008157. In accordance with the results of real-time quantitative fluorescence PCR, ceRNAs of apparently differentially expressed circ0000082, circ0023988 and circ0008157 were found by 
A

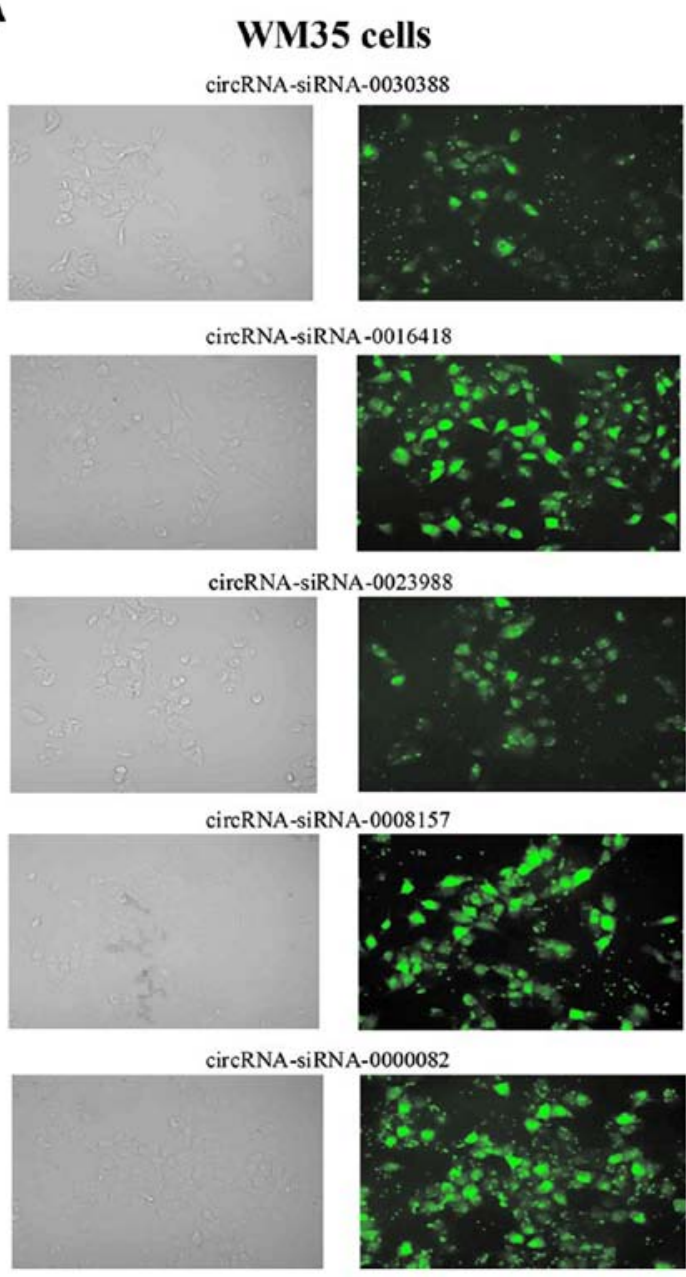

B

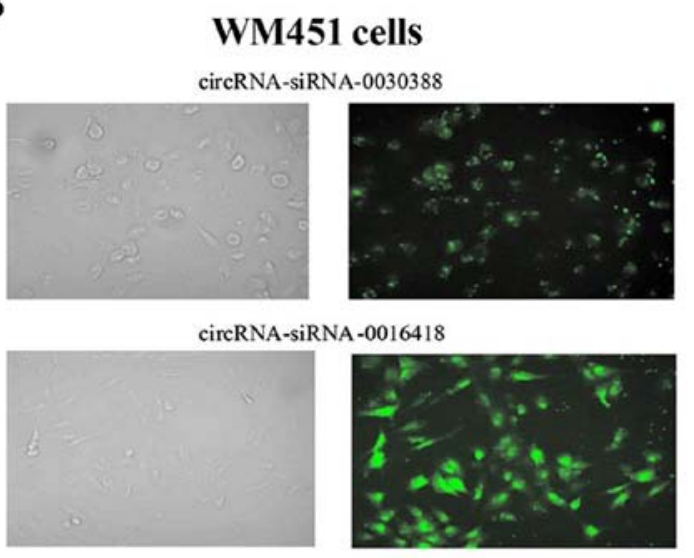

circRNA-siRNA-0023988

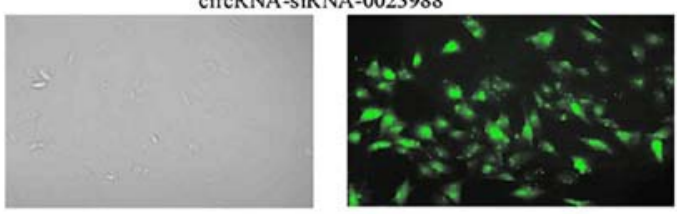

circRNA-siRNA-0008157

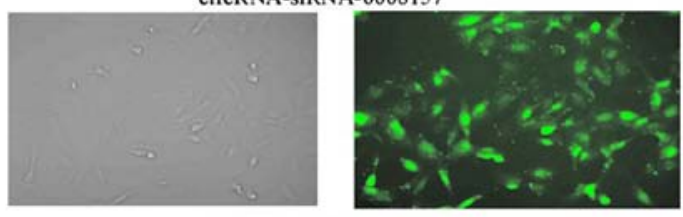

circRNA-siRNA-0000082

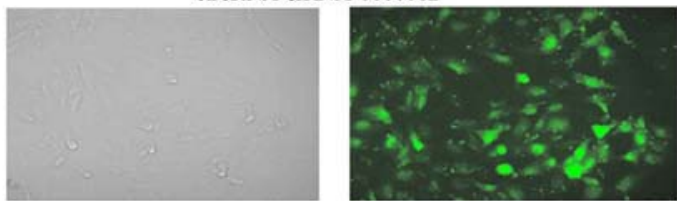

Figure 3. Validation of siRNA-circRNAs transfection in WM35 and WM451 cells. (A) WM35 and (B) WM451 cells were transfected with siRNA-circ0023988, siRNA-circ0016418, siRNA-circ0023988, siRNA-circ0008157 or siRNA-circ0000082. Representative bright field microscopy (x100 magnification, left panel) and fluorescent microscopic images (x100 magnification, right panel) are visible in the left panel.

A

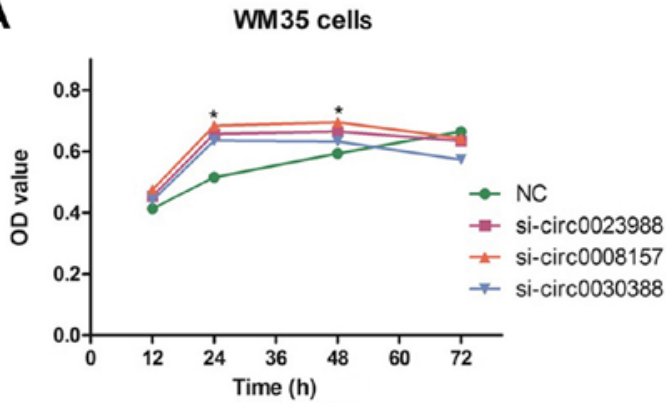

B

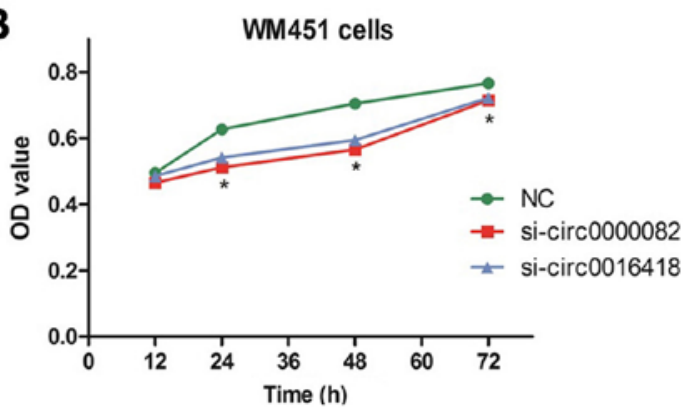

Figure 4. Cell proliferation after siRNA-circRNAs transfection. The proliferation of WM35 and WM451 cells was detected by an MTT assay. (A) Silencing of circ 0023988 , circ0008157 and circ0030388 significantly promoted cell viability in low-metastatic melanoma WM35 cells. (B) Cell proliferation was inhibited after knockdown of circ0000082 and circ0016418 in high-metastatic melanoma WM451 cells. The cells were transfected with negative control RNA oligonucleotides set as the control group (NC). ${ }^{*} \mathrm{P}<0.05$.

mutually targeted MRE enrichment analysis (MuTaME, https://cm.jefferson.edu/rna22/Precomputed/) and then a regulatory network of circRNA-miRNA-mRNA was constructed using Cytoscape 3.01 (Fig. 6). Prediction results (Table V) revealed that circ 0000082 possibly competitively bound to 64 miRNAs and impacted the expression of 425 target genes. Furthermore, circ0023988 possibly competitively bound to
78 miRNAs and impacted the expression of 33 target genes. In addition, circ 0008157 possibly competitively bound to 111 miRNAs and impacted the expression of 52 target genes. Subsequently, combining with the confirmed melanomarelated miRNAs, we selected miRNAs that impacted the occurrence and development of melanoma, competitively binding to circ0000082, circ0023988 and circ0030388 and 
A

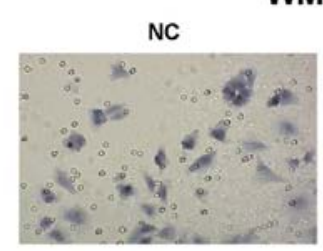

WM35

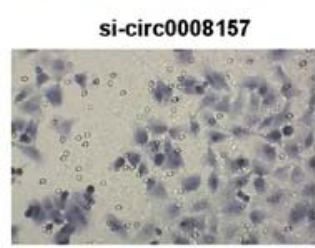

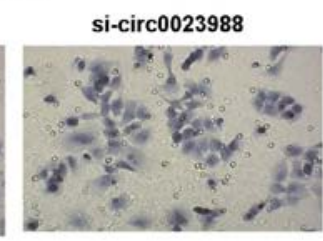

si-circ0030388

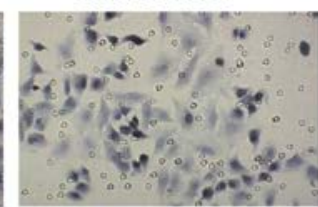

Invasion

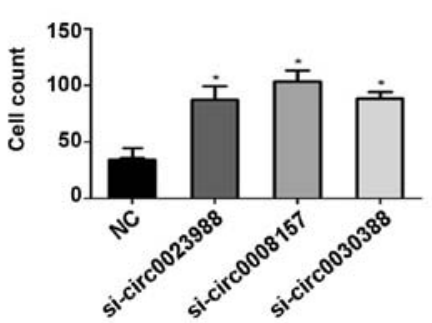

B
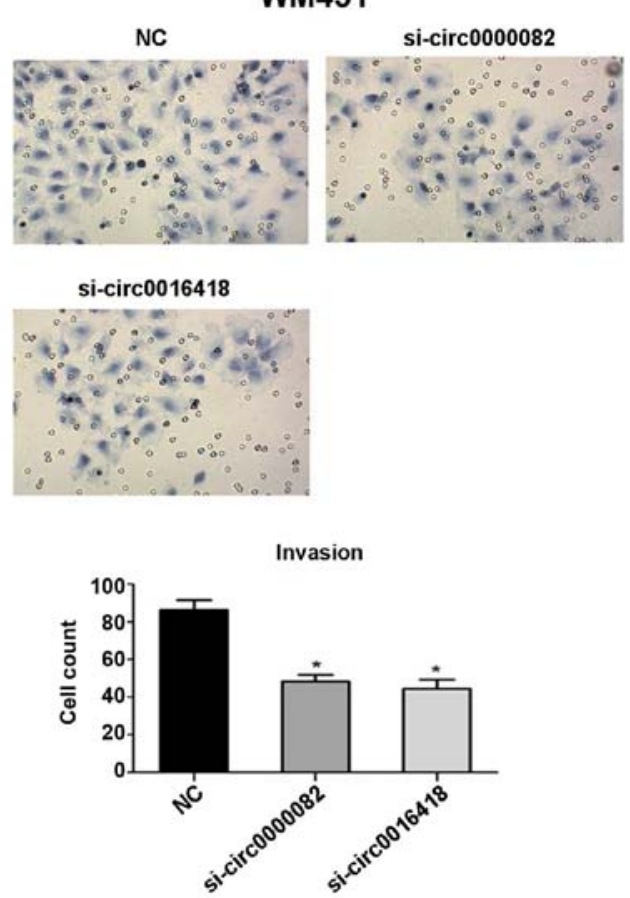

Figure 5. Invasion ability after siRNA-circRNAs transfection. The invasion of melanoma cells was detected by Transwell assay (x200 magnification). (A) Cell invasion was inhibited after knockdown of circ0023988, circ0008157 and circ0030388 in WM35 cells by transfection of siRNA-circRNA. An histogram of the WM35 cell invasion ability of each group after transfection is displayed in the bottom. (B) The downregulation of circ0000082 and circ0016418 markedly suppressed the WM451 cell invasion ability. ${ }^{*} \mathrm{P}<0.05$.

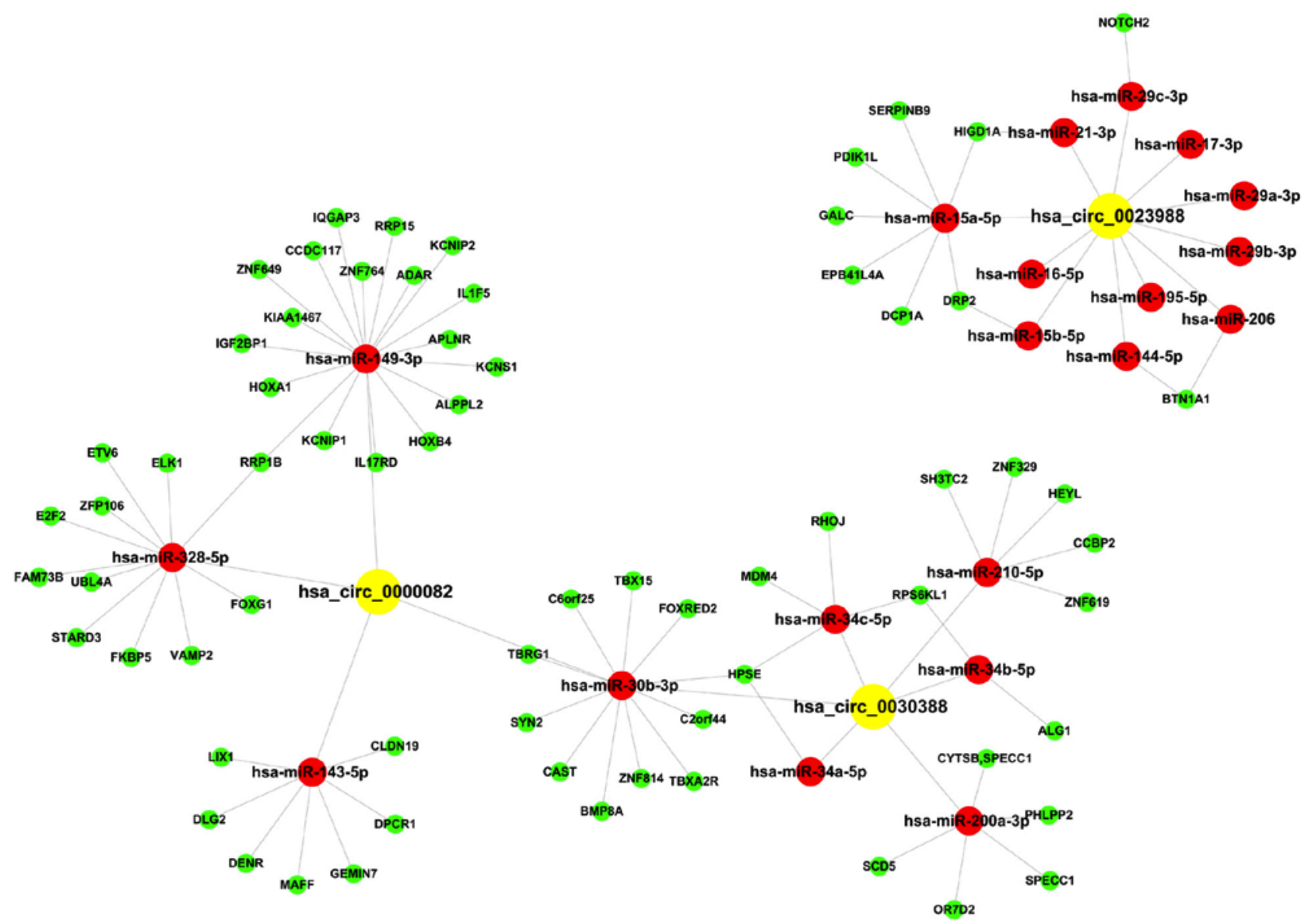

Figure 6. Biomathematical predicted circRNA-miRNA-mRNA network. MuTaMe analysis was used to predict the circRNA-microRNA-mRNA regulatory network of circ0000082, circ0023988 and circ0030388. Prediction of melanoma-related miRNAs competitively binding to circ0000082, circ0023988 and circ0030388 and the possible impacted target genes. Yellow: circRNA; Red: miRNA; Green: Target gene mRNA. 
Table V. Predicted ceRNAs for circRNAs.

\begin{tabular}{lcc}
\hline circRNA & $\begin{array}{c}\text { Sponge miRNA } \\
\text { numbers }\end{array}$ & $\begin{array}{c}\text { Target gene } \\
\text { numbers }\end{array}$ \\
\hline circ0000082 & 64 & 425 \\
circ0023988 & 78 & 33 \\
circ0030388 & 111 & 52 \\
\hline
\end{tabular}

ceRNAs, competing endogenous RNA.

the possible impacted target genes (Fig. 6). The results are displayed in Table VI.

\section{Discussion}

CircRNAs are widely expressed in human cells and their expression levels can be 10-fold or higher compared to their linear isomers. Compared with traditional linear RNA (containing 5' and 3'ends), circRNAs form a covalently-closed continuous loop and cannot be affected by RNA exonuclease. Their expression is more stable and circRNAs cannot be easily degraded. Thus, circRNAs have significant superiority in the development and application of new clinical diagnostic markers (15-17). Abnormal expression of circRNAs is observed in many cancers, such as the expression of circ104912 in laryngeal squamous cell cancer (18), of circ0001649 in hepatocellular carcinoma (19) and circ001988 in colorectal cancer (20). Most circRNAs play a regulatory role at the transcriptional and post-transcriptional levels and only a few function at the transcriptional level.

Little is known about the specific biological functions of circRNAs. Several recent breakthrough studies confirmed that some circRNAs could be used as competing endogenous RNAs (ceRNAs) to exert a regulatory effect on gene expression. CircRNA molecules enrich miRNA binding sites (21), which function as miRNA sponges (22) and play an important regulatory role in disease by interacting with disease-related miRNAs. Hansen et al (12) first found that circRNA-CDRlas (also called ciRS-7) abundantly expressed in human brain tissue, is antisense to the cerebellar degeneration-related protein 1 transcript (CDR1as). CDR1as contains $70 \mathrm{miR}-7$ binding sites and plays a negative regulatory role in miR-7 as an endogenous miRNA sponge. miR-7 is an important regulatory factor for a variety of cancer-related pathways (23-26). Thus, ciRS-7 is likely to be an important regulatory factor in the development of nervous system disease and cancer $(27,28)$. In colorectal cancers, circ001569 has been identified as a sponge

Table VI. Predicted circRNA-miRNA-mRNA network in melanoma.

\begin{tabular}{|c|c|c|}
\hline circRNA & miRNA & Target gene \\
\hline \multirow[t]{4}{*}{ circRNA0000082 } & $\operatorname{miR}-30 b-3 p$ & $\begin{array}{l}\text { BMP8A, C2orf44, C6orf25, CAST, FOXRED2, HPSE, SYN2, TBRG1, } \\
\text { TBX15, TBXA2R, ZNF814 }\end{array}$ \\
\hline & $\operatorname{miR}-143-5 p^{[44]}$ & CLDN19, DENR, DLG2, DPCR1, GEMIN7, LIX1, MAFF \\
\hline & $\operatorname{miR}-149-3 p^{[45]}$ & $\begin{array}{l}\text { ADAR, ALPPL2, APLNR, CCDC117, HOXA1, HOXB4, IGF2BP1, IL1F5, } \\
\text { IL17RD, IQGAP3, KCNIP2, KCNS1, KCNIP1, KIAA1467, RRP15, } \\
\text { RRP1B, ZNF649, ZNF764 }\end{array}$ \\
\hline & $\operatorname{miR}-328-5 p^{[46]}$ & $\begin{array}{l}\text { ELK1, ETV6, E2F2, FAM73B, FKBP5, FOXG1, RRP1B, STARD3, } \\
\text { UBL4A, VAMP2, ZFP106 }\end{array}$ \\
\hline \multirow[t]{6}{*}{ circRNA0030388 } & $\operatorname{miR}-30 b-3 p$ & $\begin{array}{l}\text { BMP8A, CAST, C2orf44, C6orf25, FOXRED2, HPSE, SYN2, TBRG1, } \\
\text { TBX15, TBXA2R, ZNF814 }\end{array}$ \\
\hline & $\operatorname{miR}-34 a-5 p^{[47]}$ & HPSE \\
\hline & $\operatorname{miR}-34 b-5 p$ & ALG1, RPS6KL1 \\
\hline & $\operatorname{miR}-34 c-5 p$ & HPSE, MDM4, RHOJ, RPS6KL1 \\
\hline & $\operatorname{miR}-200 a-3 p^{[49]}$ & CYTSB, OR7D2, PHLPP2, SCD5, SPECC1 \\
\hline & $\operatorname{miR}-210-5 p$ & CCBP2, HEYL, SH3TC2, ZNF329, ZNF619 \\
\hline \multirow[t]{6}{*}{ circRNA0023988 } & $\begin{array}{l}\operatorname{miR}-15 a-5 p \\
\operatorname{miR}-15 b-5 p^{[50]} \\
\text { miR-16-5p } \\
\text { miR-17-3p }\end{array}$ & DCP1A, DRP2, EPB41L4A, GALC, HIGD1A, PDIK1L, SERPINB9 \\
\hline & $\begin{array}{l}\operatorname{miR}-21-3 p^{[51]} \\
\operatorname{miR}-29 a-3 p^{[53]} \\
\operatorname{miR}-29 b-3 p^{[53]}\end{array}$ & HIGD1A \\
\hline & $\operatorname{miR}-29 c-3 p^{[53]}$ & NOTCH2 \\
\hline & $\operatorname{miR}-144-5 p^{[55]}$ & BTN1A1 \\
\hline & $\operatorname{miR}-195-5 \mathrm{p}^{[54]}$ & \\
\hline & miR-206 & \\
\hline
\end{tabular}


Table VII. Functions of potential miRNAs target circRNAs.

\begin{tabular}{|c|c|c|c|c|}
\hline circRNA & miRNA & Cancer & Target gene & Function \\
\hline circRNA0001056 & miR-665 & GSRCC & & Invasion, metastasis, chemosensitivity \\
\hline \multirow[t]{2}{*}{ circRNA0000082 } & $\operatorname{miR}-508-5 p$ & Gastric cancer & $\begin{array}{l}\mathrm{ABCB} 1^{[38]} \\
\mathrm{ZNRD} 1^{[38]}\end{array}$ & Chemosensitivity \\
\hline & $\operatorname{miR}-143-5 p$ & $\begin{array}{l}\text { CRC, gastric } \\
\text { cancer }\end{array}$ & $\mathrm{COX}-2$ & Invasion and metastasis \\
\hline \multirow[t]{2}{*}{ circRNA0016418 } & miR-214-5p & $\mathrm{HCC}$ & & \\
\hline & $\operatorname{miR}-657$ & $\begin{array}{l}\text { HCC, laryngeal } \\
\text { carcinoma }\end{array}$ & TLE1 $1^{[39]}$ & Proliferation \\
\hline \multirow[t]{4}{*}{ circRNA0008602 } & miR-362-5p & $\mathrm{HCC}$ & CYLD & Proliferation, clone, invasion and metastasis \\
\hline & miR-544a & NSCLC & CDH1 & Proliferation, clone, invasion and metastasis \\
\hline & $\operatorname{miR}-200 c-3 p$ & CRC, ovarian cancer & & \\
\hline & miR-17 & $\begin{array}{l}\mathrm{PCa}, \mathrm{CRC}, \mathrm{HCC} \\
\text { glioblastoma }^{[41]}\end{array}$ & $\begin{array}{l}\text { TIMP3, PTEN } \\
\text { GalNT7 }^{[40]} \\
\text { DNA-PK MDM2 }\end{array}$ & $\begin{array}{l}\text { Proliferation, invasion and metastasis; } \\
\text { cell cycle, angiogenesis; radiation } \\
\text { and chemotherapy sensitivity }\end{array}$ \\
\hline \multirow[t]{3}{*}{ circRNA0033496 } & $\operatorname{miR}-612$ & $\mathrm{HCC}$ & $\mathrm{AKT}^{[43]}$ & Proliferation, invasion and metastasis \\
\hline & $\operatorname{miR}-502-5 p$ & CRC, breast cancer & $\mathrm{Rab} \mathrm{B}^{[42]}, \mathrm{TRAF} 2$ & Proliferation, cell cycle, apoptosis \\
\hline & $\operatorname{miR}-423-5 p$ & $\begin{array}{l}\mathrm{PC}, \mathrm{CRC}, \mathrm{HCC} \\
\text { gastric cancer }\end{array}$ & $\beta$-catenin, TFF1 & $\begin{array}{l}\text { Proliferation, invasion and metastasis; } \\
\text { cell cycle; apoptosis; chemosensitivity }\end{array}$ \\
\hline circRNA0023990 & $\operatorname{miR}-339-5 p$ & $\begin{array}{l}\text { NSCLC, CRC, } \\
\text { breast cancer }\end{array}$ & $\begin{array}{l}\text { BCL-6 }{ }^{[32]}, \text { PRL-1 }^{[31]} \\
\operatorname{MDM}^{[33]}\end{array}$ & Proliferation, invasion and metastasis \\
\hline \multirow[t]{3}{*}{ circRNA0030388 } & $\operatorname{miR}-449 a$ & $\begin{array}{l}\text { NSCLC, MM, } \\
\text { gastric cancer, } \\
\text { ovarian cancer, } \\
\text { glioblastoma, } \\
\text { endometrial cancer }\end{array}$ & $\begin{array}{l}\text { c-MET } \\
\text { lncRNA NEAT1 } \\
\text { E2F3, NOTCH1 } 1^{[36]} \\
\text { CDK6, MAZ }\end{array}$ & $\begin{array}{l}\text { Proliferation, cell cycle; apoptosis; } \\
\text { chemotherapy sensitivity }\end{array}$ \\
\hline & $\operatorname{miR}-34 c-5 p$ & $\begin{array}{l}\text { CRC, PCa, } \\
\text { glioblastoma, } \\
\text { NPC, endometrial } \\
\text { cancer }\end{array}$ & $\begin{array}{l}\text { Notch }^{[34]}, \text { Bmf } \\
\text { c-myc, E2F3 } \\
\text { MAPT }\end{array}$ & $\begin{array}{l}\text { Cell cycle; apoptosis; radiation and } \\
\text { chemotherapy sensitivity }\end{array}$ \\
\hline & $\operatorname{miR}-200 a-3 p$ & $\begin{array}{l}\text { Ovarian cancer, } \\
\text { glioblastoma }\end{array}$ & $\operatorname{MGMT}^{[35]}$ & Chemotherapy sensitivity \\
\hline
\end{tabular}

GSRCC, gastric signet ring cell carcinoma; PC, pancreatic carcinoma; CRC, colorectal cancer; NSCLC, non-small cell lung cancer; PCa, prostatic cancer; MM, melanoma.

of miR-145, which can inhibit tumor development through the upregulation of the expression of miR-145 target genes E2F5, BAG4 and FMNL2 (29). In bladder carcinomas, circTCF25 acts as a sponge for miR-103a and miR-107 which downregulate the expression of CDK6 and promote cell proliferation and migration (30). The above-mentioned studies indicate that circRNAs also function as ceRNAs, reveal a new regulation mode of circRNA on target genes by competitively binding to miRNA and reveal that circRNAs participate in various physiological and pathological processes.

The present study demonstrated that hundreds of circRNAs are differentially expressed in melanoma cell lines and normal melanocytes. Further comprehensive analysis revealed that the expression of circ0001056, circ0000082, circ0016418, circ0008602 and circ0033496 was upregulated in the WM35 and WM451 cells, indicating that they may play a similar role as cancer-promoting genes in the occurrence and development of melanoma. In WM35 vs. HM cells, WM451 vs. HM cells and WM451 vs. WM35 cells, the expression of circ0023988, circ0023990, circ0008157 and circ0030388 was downregulated. In combination with numerous previous studies (31-43), our prediction results of the miRNA binding sites on the above-mentioned circRNAs using Arraystar miRNA target prediction software and GCBI (https://www.gcbi.com. $\mathrm{cn} / \mathrm{gclib} / \mathrm{html} /$ index) based on TargetScan and miRanda software revealed that miR-143-5p, miR-449a, miR-657, miR-200c-3p and miR-423-5p were abnormally expressed in a variety of tumor tissues (colorectal cancer, lung adenocarcinoma, breast, liver and ovarian cancer). The related target genes are involved in proliferation, apoptosis and cell cycle of various malignant tumor cells by participating in the Wnt/ $\beta$-catenin, Notch, PI3K/AKT, NF- $\kappa \mathrm{B}, \mathrm{p} 53$, autophagy, angiogenesis and other signaling pathways. They produce a marked effect on tumorigenesis, invasion, metastasis and sensitivity to 
radiotherapy and chemotherapy (Table VII). Based on the results of qRT-PCR, significantly differentially-expressed circRNAs were silenced using siRNA interference, and then transfected into WM35 and WM45 cells. Compared with the WM451 cells, the proliferation and invasion of WM35 cells were promoted after the upregulated circRNAs (circ0023988, circ0008157 and circ0030388) in low-metastatic melanoma WM35 cells were silenced. Compared with the WM35 cells, the silencing of the upregulated circRNAs (circ0000082 and circ0016418) in high-metastatic melanoma WM451 cells inhibited the proliferation and invasion of WM451 cells, confirming that circ0030388, circ0016418, circ0023988, circ0008157 and circ0000082 were closely related to the proliferation and invasion of melanoma cells. The ceRNAs of circ0000082, circ0023988 and circ0008157 were further analyzed using MuTaMe. Many predicted miRNAs and target genes have been verified to be strongly associated with the proliferation, invasion and metastasis of melanoma in previous studies (44-55) (Table VI). Although, the present study has identified the abnormally expressed circRNAs in MM cell lines, confirmed the adverse or positive effect on tumor development of five specific circRNAs and predicted the potential biological functions by previously reported circRNA-miRNA-mRNA networks, several limitations still exist. Only cell viability and invasion abilities of the identified circRNAs were evaluated, therefore it would be better to investigate other deeper functions in a future study, such as the regulation on cell material and energy metabolism, tumor metastasis or immune function. In addition, for the predicted circRNA targets, including miRNAs and mRNAs, more research is warranted to clarify in detail the underlying mechanisms of such circRNAs. Subsequently, on the basis of predicted miRNA, we will combine a microarray of mRNA sequencing before and after the predicted circRNA silencing and attempt to examine changes of the target genes. We may reveal the exact regulatory mechanisms of the circRNAmiRNA-mRNAs network which influence the occurrence and development of melanoma. Finally, we will analyze the effects of differentially expressed circRNAs combined miRNAs and target genes on melanoma according to the pathological type and prognosis of melanoma patients.

\section{Acknowledgements}

The present study was supported by grants from the National Natural Science Foundation of China (nos. 8130168, 81272192 and 81171882) and the Hunan Natural Science Foundation (no. 2015JJ4053).

\section{Competing interests}

The authors declare that they have no competing interests.

\section{References}

1. Egan KM, Seddon JM, Glynn RJ, Gragoudas ES and Albert DM: Epidemiologic aspects of uveal melanoma. Surv Ophthalmol 32: 239-251, 1988.

2. Kam R, Hayungs J, Bomfeld N, Sauerwein W, Höffken K and Seeber S: Prognosis and treatment of disseminated uveal melanoma. Cancer 72: 2219-2223, 1993.
3. Qu S, Yang X, Li X, Wang J, Gao Y, Shang R, Sun W, Dou K and Li H: Circular RNA: A new star of noncoding RNAs. Cancer Lett 365: 141-148, 2015.

4. Chen LL: The biogenesis and emerging roles of circular RNAs. Nat Rev Mol Cell Biol 17: 205-211, 2016.

5. Li J, Yang J, Zhou P, Le Y, Zhou C, Wang S, Xu D, Lin HK and Gong Z: Circular RNAs in cancer: Novel insights into origins, properties, functions and implications. Am J Cancer Res 5: 472-480, 2015.

6. Wang F, Nazarali AJ and Ji S: Circular RNAs as potential biomarkers for cancer diagnosis and therapy. Am J Cancer Res 6: 1167-1176, 2016.

7. Shao Y and Chen Y: Roles of circular RNAs in neurologic disease. Front Mol Neurosci 9: 25, 2016.

8. Lu D and Xu AD: Mini review: Circular RNAs as potential clinical biomarkers for disorders in the central nervous system. Front Genet 7: 53, 2016

9. Li Z, Huang C, Bao C, Chen L, Lin M, Wang X, Zhong G, Yu B, $\mathrm{Hu}$ W, Dai L, et al: Exon-intron circular RNAs regulate transcription in the nucleus. Nat Struct Mol Biol 22: 256-264, 2015.

10. Ashwal-Fluss R, Meyer M, Pamudurti NR, Ivanov A, Bartok O, Hanan M, Evantal N, Memczak S, Rajewsky N and Kadener S: circRNA biogenesis competes with pre-mRNA splicing. Mol Cell 56: 55-66, 2014

11. Hansen TB, Jensen TI, Clausen BH, Bramsen JB, Finsen B, Damgaard CK and Kjems J: Natural RNA circles function as efficient microRNA sponges. Nature 495: 384-388, 2013.

12. Hansen TB, Kjems J and Damgaard CK: Circular RNA and miR-7 in cancer. Cancer Res 73: 5609-5612, 2013.

13. Memczak S, Jens M, Elefsinioti A, Torti F, Krueger J, Rybak A, Maier L, Mackowiak SD, Gregersen LH, Munschauer M, et al: Circular RNAs are a large class of animal RNAs with regulatory potency. Nature 495: 333-338, 2013.

14. Li F, Zhang L, Li W, Deng J, Zheng J, An M, Lu J and Zhou Y: Circular RNA ITCH has inhibitory effect on ESCC by suppressing the Wnt/ $\beta$-catenin pathway. Oncotarget 6: 6001-6013, 2015.

15. Jeck WR, Sorrentino JA, Wang K, Slevin MK, Burd CE, Liu J, Marzluff WF and Sharpless NE: Circular RNAs are abundant, conserved, and associated with ALU repeats. RNA 19: 141-157, 2013.

16. Suzuki H,Zuo Y, Wang J, Zhang MQ, Malhotra A and Mayeda A: Characterization of RNase R-digested cellular RNA source that consists of lariat and circular RNAs from pre-mRNA splicing. Nucleic Acids Res 34: e63, 2006.

17. Suzuki $\mathrm{H}$ and Tsukahara T: A view of pre-mRNA splicing from RNase R resistant RNAs. Int J Mol Sci 15: 9331-9342, 2014.

18. Xuan L, Qu L, Zhou H, Wang P, Yu H, Wu T, Wang X, Li Q, Tian L, Liu M and Sun Y: Circular RNA: A novel biomarker for progressive laryngeal cancer. Am J Transl Res 8: 932-939, 2016.

19. Qin M, Liu G, Huo X, Tao X, Sun X, Ge Z, Yang J, Fan J, Liu L and Qin W: Hsa_circ_0001649: A circular RNA and potential novel biomarker for hepatocellular carcinoma. Cancer Biomark 16: 161-169, 2016.

20. Wang X, Zhang Y, Huang L, Zhang J, Pan F, Li B, Yan Y, Jia B, Liu H, Li S and Zheng W: Decreased expression of hsa_circ_001988 in colorectal cancer and its clinical significances. Int J Clin Exp Pathol 8: 16020-16025, 2015.

21. Hansen TB, Wiklund ED, Bramsen JB, Villadsen SB, Statham AL, Clark SJ and Kjems J: miRNA-dependent gene silencing involving Ago2-mediated cleavage of a circular antisense RNA. EMBO J 30: 4414-4422, 2011.

22. Valdmanis PN and Kay MA: The expanding repertoire of circular RNAs. Mol Ther 21: 1112-1114, 2013.

23. Kefas B, Godlewski J, Comeau L, Li Y, Abounader R, Hawkinson M, Lee J, Fine H, Chiocca EA, Lawler S and Purow B: microRNA-7 inhibits the epidermal growth factor receptor and the Akt pathway and is down-regulated in glioblastoma. Cancer Res 68: 3566-3572, 2008.

24. Reddy SD, Ohshiro K, Rayala SK and Kumar R: MicroRNA-7, a homeobox D10 target, inhibits p21-activated kinase 1 and regulates its functions. Cancer Res 68: 8195-8200, 2008.

25. Webster RJ, Giles KM, Price KJ, Zhang PM, Mattick JS and Leedman PJ: Regulation of epidermal growth factor receptor signaling in human cancer cells by microRNA-7. J Biol Chem 284: 5731-5741, 2009.

26. Xiong S, Zheng Y, Jiang P, Liu R, Liu X and Chu Y: MicroRNA-7 inhibits the growth of human non-small cell lung cancer A549 cells through targeting BCL-2. Int J Biol Sci 7: 805-814, 2011. 
27. Rybak-Wolf A, Stottmeister C, Glazar P, Jens M, Pino N, Giusti S, Hanan M, Behm M, Bartok O, Ashwal-Fluss R, et al: Circular RNAs in the mammalian brain are highly abundant, conserved, and dynamically expressed. Mol Cell 58: 870-885, 2015.

28. Peng L, Yuan XQ and Li GC: The emerging landscape of circular RNA ciRS-7 in cancer. Oncol Rep 33: 2669-2674, 2015.

29. Xie H, Ren X, Xin S, Lan X, Lu G, Lin Y, Yang S, Zeng Z, Liao W, Ding YQ and Liang L: Emerging roles of circRNA 001569 targeting miR-145 in the proliferation and invasion of colorectal cancer. Oncotarget 7: 26680-26691, 2016.

30. Zhong Z, Lv M and Chen J: Screening differential circular RNA expression profiles reveals the regulatory role of circTCF25-miR103a-3p/miR-107-CDK6 pathway in bladder carcinoma. Sci Rep 6: 30919, 2016.

31. Zhou C, Liu G, Wang L, Lu Y, Yuan L, Zheng L, Chen F, Peng F and $\mathrm{Li} \mathrm{X}$ : MiR-339-5p regulates the growth, colony formation and metastasis of colorectal cancer cells by targeting PRL-1. PLoS One 8: e63142, 2013.

32. Wu ZS, Wu Q, Wang CQ, Wang XN, Wang Y, Zhao JJ, Mao SS, Zhang GH, Zhang N and Xu XC: MiR-339-5p inhibits breast cancer cell migration and invasion in vitro and may be a potential biomarker for breast cancer prognosis. BMC Cancer 10: 542 , 2010.

33. Zhang C, Liu J, Wang X, Wu R, Lin M, Laddha SV, Yang Q, Chan CS and Feng Z: MicroRNA-339-5p inhibits colorectal tumorigenesis through regulation of the MDM2/p53 signaling. Oncotarget 5: 9106-9117, 2014.

34. Wu Z, Wu Y, Tian Y, Sun X, Liu J, Ren H, Liang C, Song L, $\mathrm{Hu} \mathrm{H}$, Wang L and Jiao B: Differential effects of miR-34c-3p and $\mathrm{miR}-34 \mathrm{c}-5 \mathrm{p}$ on the proliferation, apoptosis and invasion of glioma cells. Oncol Lett 6: 1447-1452, 2013.

35. Berthois Y, Delfino C, Metellus P, Fina F, Nanni-Metellus I, Al Aswy H, Pirisi V, Ouafik L and Boudouresque F: Differential expression of miR-200a-3p and miR21 in grade II-III and grade IV gliomas: Evidence that miR-200a-3p is regulated by $\mathrm{O}^{6}$-methylguanine methyltransferase and promotes temozolomide responsiveness. Cancer Biol Ther 15: 938-950, 2014.

36. Zhou Y, Chen Q, Qin R, Zhang K and Li H: MicroRNA-449a reduces cell survival and enhances cisplatin-induced cytotoxicity via downregulation of NOTCH1 in ovarian cancer cells. Tumou Biol 35: 12369-12378, 2014.

37. Yao Y, Ma J, Xue Y, Wang P, Li Z, Li Z, Hu Y, Shang X and Liu Y: MiR-449a exerts tumor-suppressive functions in human glioblastoma by targeting Myc-associated zinc-finger protein. Mol Oncol 9: 640-656, 2015 .

38. Shang Y, Zhang Z, Liu Z, Feng B, Ren G, Li K, Zhou L, Sun Y, $\mathrm{Li}$ M, Zhou J, et al: miR-508-5p regulates multidrug resistance of gastric cancer by targeting ABCB1 and ZNRD1. Oncogene 33: 3267-3276, 2014

39. Zhang L, Yang L, Liu X, Chen W, Chang L, Chen L, Loera S, Chu P, Huang WC, Liu YR and Yen Y: MicroRNA-657 promotes tumorigenesis in hepatocellular carcinoma by targeting transducin-like enhancer protein 1 through nuclear factor kappa B pathways. Hepatology 57: 1919-1930, 2013.

40. Shan SW, Fang L, Shatseva T, Rutnam ZJ, Yang X, Du W, Lu WY, Xuan JW, Deng Z and Yang BB: Mature miR-17-5p and passenger miR-17-3p induce hepatocellular carcinoma by targeting PTEN, GalNT7 and vimentin in different signal pathways. J Cell Sci 126: 1517-1530, 2013.
41. Chaudhry MA, Sachdeva H and Omaruddin RA: Radiationinduced micro-RNA modulation in glioblastoma cells differing in DNA-repair pathways. DNA Cell Biol 29: 553-561, 2010.

42. Zhai H, Song B, Xu X, Zhu W and Ju J: Inhibition of autophagy and tumor growth in colon cancer by miR-502. Oncogene 32 1570-1579, 2013.

43. Tang J, Tao ZH, Wen D, Wan JL, Liu DL, Zhang S, Cui JF, Sun HC, Wang L, Zhou J, et al: MiR-612 suppresses the stemness of liver cancer via Wnt $/ \beta$-catenin signaling. Biochem Biophys Res Commun 447: 210-215, 2014.

44. Li R, Zhang L, Jia L, Duan Y, Li Y, Wang J, Bao L and Sha N: MicroRNA-143 targets Syndecan-1 to repress cell growth in melanoma. PLoS One 9: e94855, 2014.

45. Jin L, Hu WL, Jiang CC, Wang JX, Han CC, Chu P, Zhang LJ, Thorne RF, Wilmott J, Scolyer RA, et al: MicroRNA-149*, a p53-responsive microRNA, functions as an oncogenic regulator in human melanoma. Proc Natl Acad Sci USA 108: 15840-15845, 2011.

46. Li JR, Wang JQ, Gong Q, Fang RH and Guo YL: MicroRNA-328 inhibits proliferation of human melanoma cells by targeting TGF32. Asian Pac J Cancer Prev 16: 1575-1579, 2015.

47. Liu R, Xie H, Luo C, Chen Z, Zhou X, Xia K, Chen X, Zhou M, Cao P, Cao K and Zhou J: Identification of FLOT2 as a novel target for microRNA-34a in melanoma. J Cancer Res Clin Oncol 141: 993-1006, 2015.

48. Zhou J, Xu D, Xie H, Tang J, Liu R, Li J, Wang S, Chen X, Su J, Zhou X, et al: miR-33a functions as a tumor suppressor in melanoma by targeting HIF-1 $\alpha$. Cancer Biol Ther 16: 846-855, 2015.

49. Elson-Schwab I, Lorentzen A and Marshall CJ: MicroRNA-200 family members differentially regulate morphological plasticity and mode of melanoma cell invasion. PLoS One 5: pii:e13176, 2010.

50. Satzger I, Mattern A, Kuettler U, Weinspach D, Voelker B, Kapp A and Gutzmer R: MicroRNA-15b represents an independent prognostic parameter and is correlated with tumor cell proliferation and apoptosis in malignant melanoma. Int J Cancer 126: 2553-2562, 2010.

51. Martin de Campo SE, Latchana N, Levine KM, Grignol VP, Fairchild ET, Jaime-Ramirez AC, Dao TV, Karpa VI, Carson M, Ganju A, et al: MiR-21 enhances melanoma invasiveness via inhibition of tissue inhibitor of metalloproteinases 3 expression: In vivo effects of MiR-21 inhibitor. PLoS One 10: e0115919, 2015.

52. Zhou J, Liu R, Wang Y, Tang J, Tang S, Chen X, Xia K, Xiong W, $\mathrm{Xu} \mathrm{D}$, Wang S, et al: miR-199a-5p regulates the expression of metastasis-associated genes in B16F10 melanoma cells. Int J Clin Exp Pathol 7: 7182-7190, 2014.

53. Schmitt MJ, Philippidou D, Reinsbach SE, Margue C, Wienecke-Baldacchino A, Nashan D, Behrmann I and Kreis S: Interferon- $\gamma$-induced activation of signal transducer and activator of transcription 1 (STAT1) up-regulates the tumor suppressing microRNA-29 family in melanoma cells. Cell Commun Signal 10: 41, 2012.

54. Bhattacharya A, Schmitz U, Wolkenhauer O, Schönherr M, Raatz Y and Kunz M: Regulation of cell cycle checkpoint kinase WEE1 by miR-195 in malignant melanoma. Oncogene 32: 3175-3183, 2013.

55. Sun L, Bian G, Meng Z, Dang G, Shi D and Mi S: MiR-144 inhibits uveal melanoma cell proliferation and invasion by regulating c-Met expression. PLoS One 10: e0124428, 2015. 